\title{
KITAB SYARAH DAN TRADISI INTELEKTUAL PESANTREN
}

\author{
Suwarjin \\ Fakultas Ushuluddin, Adab, Dakwah IAIN Bengkulu \\ Jl. Raden Fatah Pagar Dewa Bengkulu \\ Email: siajima@yahoo.com
}

\begin{abstract}
Book of syarah is one form of creativity of ulama thought in writing of book. Like the work of matn, hasyiyah, ta'liqat or other, syarh has a certain degree of authenticity that deserves to be appreciated as a work of thought. Precisely, through the tradition of writing syarah the writing of the book developed very rapidly. Therefore, the syarh book dominates and outperforms the work in other forms of quantity. This happens because a single book of matan can be passed into several books, as happened in the mat-at-Taqrib. In terms of weight of content, the book syarh basically provides a wider discussion to the reader who also mark the level or increase in the level of learning process. However, it must be admitted that the book of syarh has some weaknesses, such as a high degree of plagiarism, imitative nature and takes a long time to learn it. However, the weakness does not make the book shrug of urgency in the tradition of Islamic scholarship that highly appreciate the work of the previous scholars. Book of syarh by the pesantren is received with honor and respect as the fruit of creativity of pthought and berijtihad.
\end{abstract}

Keywords: syarh, inltelectual tradition, Islamic boarding school

\begin{abstract}
Abstrak: Kitab syarah merupakan salah satu bentuk kreatifitas pemikiran ulama dalam penulisan kitab. Seperti halnya karya matn, hasyiyah, ta'liqat atau lainnya, syarh memiliki kadar otentisitas tertentu yang patut diapresiasi sebagai karya pemikiran. Justru, melalui tradisi penulisan syarah penulisan kitab turas berkembang sangat pesat. Oleh sebab itu, kitab syarh mendominasi dan mengungguli karya dalam bentuk lain dari segi jumlah. Hal ini terjadi lantaran satu kitab matan dapat disyarhkan kedalam beberapa kitab, seperti yang terjadi pada matn al-Taqrib. Dari segi bobot isi, kitab syarh pada dasarnya memberikan pembahasan yang lebih luas kepada pembaca yang sekaligus menandai jenjang atau kenaikan tingkat dalam proses pembelajaran. Namun demikian, harus diakui bahwa kitab syarh memiliki beberapa kelemahan, seperti kadar plagiasi yang cukup tinggi, sifat imitatif dan memerlukan waktu lama untuk mempelajarinya. Akan tetapi kelemahan tersebut tidak menjadikan kitab syarh kehilangan urgensi dlam tradisi keilmuan pesantren yang sangat menghargai karya ulama terdahulu. Kitab syarh oleh kalangan pesantren diterima dengan penuh penghargaan dan penghormatan sebagai buah dari kreativitas berpikir dan berijtihad.
\end{abstract}

Kata kunci: syarh, tradisi intelektual, pesantren

\section{Pendahuluan}

Salah satu produk pemikiran yang berkembang sampai saat ini adalah tradisi kitab kuning (kutub al-turâts). Kitab kuning merupakan tradisi agung (great tradition) yang berkembang di kalangan pesantren, lembaga pendidikan milik kaum tradisionalis. ${ }^{1}$ Dinamakan kitab kuning, karena

\footnotetext{
${ }^{1}$ Sekarang, pesantren bukan lagi monopoli kaum tradisionalis, kaum modernis juga mendirikan sejumlah pesantren di tanah air, meskipun pemilihan kitab yang diajarkan berbeda dengan kitabkitab yang diajarkan di pesantren kaum tradisionalis. Di samping perbedaan jenis kitab yang diajarkan, kedudukan kitab dalam sistem kurikulum serta intensitas pengajaran dan metodenya juga berbeda.
}

pada masa lalu, kitab ini dicetak di atas kertas yang berwarna kuning. Pada mulanya, sebutan 'kitab kuning' diberikan pihak luar pesantren sebagai sebutan yang bernada pejoratif, sebab, kertas kuning umumnya berkualitas rendah. Namun, lama-kelamaan sebutan tersebut diterima kalangan pesantren dan menjadi trade mark yang menarik. ${ }^{2}$ Kitab-kitab tersebut memuat penjelasan berbagai disiplin ilmu keislama, seperti tafsir, hadis, syarah hadis, tauhid, tata bahasa dan sastra Arab, ahlak,

${ }^{2}$ Affandi Mochtar, Kitab Kuning dan Tradisi Akademik Pesantren, (Bekasi: Pustaka Isfahan, 2009), h. 32. 
tasawuf, pedoman doa dan kisah para nabi, ushul fikih dan fikih. ${ }^{3}$ Kitab-kitab tersebut ada yang berbentuk matan, syarah dan hâsyiyah, namun sebagian besarnya, khususnya dalam bidang fikih ditulis dalam bentuk syarah.

Tidak diketahui secara persis kapan dan siapa orang pertama yang memulai tradisi penulisan kitab syarah ini. Sejarah hanya menginformasikan bahwa tradisi ini muncul sebagai dampak dari kemunduran pemikiran dalam Islam yang terjadi sejak pertengahan abad keempat hijriyah, yang otomatis mempengaruhi pemikiran fikih. Secara literer Syarah berarti penjelasan, sinonim dengan kata tafsir, yang dalam tradisi keilmuan Islam dikaitkan dengan Alquran. Stigma bahwa kitab-kitab syarah (kecuali kitab syarah hadis) merupakan produk dari fase kemunduran pemikiran dalam Islam yang karenanya berkualitas rendah tidak sepenuhnya benar. $\mathrm{Hal}$ ini perlu ditegaskan mengingat ada sebagian kelompok yang selama ini memandang produk syarah sebelah mata. Kitab-kitab syarah semestinya dipandang sebagai sebuah karya pemikiran yang memiliki posisi setara dengan produk pemikiran lain seperti matan, hâsyizah, khulâshah, ta'lîqât atau lainnya. Menurut Azyumardi Azra, seperti dikutip Maragustam, menyatakan bahwa dalam batas tertentu kitab syarah memiliki orisinalitas sebagai sebuah karya pemikiran. Sebab, aktifitas pen-syarah-an sendiri melibatkan proses kreatif, sejak memahami apa yang ditulis pengarangnya, perenungan, refleksi sampai pada pengungkapan kembali ke dalam bentuk tulisan. ${ }^{4}$

Di samping itu, orisinalitas suatu karya tidak dapat dilihat hanya dari segi bentuk karya tersebut, apakah berupa matan, syarah, hâsyizah, mukhtashar, ta'lîqât atau lainnya. Lebih-lebih lagi sebuah karya pemikiran sesungguhnya tidak ada yang murni (seratus persen) hasil pemikiran satu orang, sebab, betapapun orisinilnya sebuah karya pemikiran, ia pada dasarnya merupakan jaringan intersubyektivitas dari pemikiran orang

\footnotetext{
${ }^{3}$ Affandi Mochtar, Kitab Kuning..., h. 58.

${ }^{4}$ Maragustam, Pemikiran Pendidikan Syekh Nawawi alBantani, (Yogyakarta: Datamedia, 2007), h. 4.
}

banyak. 5 Oleh karena itu, sudah seharusnya, kitab syarah diposisikan setara atau bahkan lebih dibanding bentuk lain, karena ia mampu menyajikan uraian lebih lengkap dari pada kitab syarah.

Melalui tulisan ini, penulis bermaksud mendudukkan posisi kitab syarah sebagai suatu karya yang otoritatif untuk menjelaskan persoalanpersoalan keagamaan dan memiliki tingkat orisinalitas tertentu sebagai sebuah karya pemikiran. Jika kitab syarah yang mendominasi bahan ajar di pesantren dianggap tidak otoritatif dan tidak orisinil (imitatif belaka), maka berarti kitab-kitab tersebut tidak layak dijadikan bahan ajar, dan jika kitab syarah dianggap sebagai karya imitatif, berarti ia menyuguhkan hal-hal baru yang merepresentasikan dinamika umat Islam. Oleh karena itu perlu dijelaskan agar kitab syarah tidak dihakimi sebagai biang keladi kemunduran fikih.

\section{Asal-Usul Tradisi Keilmuan Pesantren}

Sebagai lembaga pendidikan yang memiliki cirri-cirinya sendiri, pesantren memiliki tradisi keilmuannya yang berbeda dari tradisi keilmuan lembaga-lembaga lain. ${ }^{6}$ Karena keunikannya, pesantren dipandang sebagai sebuah sub-kultur yang mengembangkan polanya sendiri. ${ }^{7}$ Menurut Abdurrahman Wahid, setidaknya ada tiga elemen yang menjadikan pesantren sebagai sub-kultur, yaitu pola kepemimpinan di dalamnya yang berada di luar kepemimpinan pemerintahan desa, literatur universalnya yang terus dipelihara selama berabad-abad, dan sistem nilainya sendiri yang terpisah dari yang diikuti oleh masyarakat luas. ${ }^{8}$ Sebagai sub-kultur, pesantren telah teruji mampu melewati sejarah panjang dan meneguhkan dirinya sebagai lembaga pendidikan yang mampu survive di tengah tekanan dan perubahan yang

\footnotetext{
${ }^{5}$ Qomaruddin Hidayat, Memahami bahasa Agama sebuah Kajian Hermeneutika, (Bandung: Mizan, 2011), h. 200.

6 Abdurrahman Wahid, Islam Kosmopolitan Nilai-Nilai Indonesia dan Transformasi Kebudayaan, (Jakarta: The Wahid Institute, 2007), h. 121.

${ }^{7}$ Affandi Mochtar, Kitab Kuning...., h. 49.

${ }^{8}$ Abdurrahman Wahid, Islam Kosmopolitan...., h. 136-137.
} 
terjadi sangat cepat. Hal ini diakui oleh Manfred Ziemek yang menyatakan bahwa lembaga pendidikan pesantren telah berkembang dalam pranata yang khas selama berabad-abad secara mandiri dan bebas dari pengaruh pendidikan Barat. $^{9}$

Menurut Azyumardi Azra, sejak dilancarkannya modernisasi pendidikan di berbagai kawasan dunia Muslim, tidak banyak lembaga tradisional Islam seperti pesantren yang mampu bertahan. Kebanyakannya lenyap setelah tergusur oleh sistim pendidikan umum atau mengalami transformasi menjadi lembaga pendidikan umum, atau setidak-tidaknya menyesuaikan diri dan sedikit-banyak mengadopsi isi dan metodologi pendidikan umum. ${ }^{10}$ Untuk menjelaskan tesisnya di atas ia mengemukakan pengalaman beberapa daerah di kawasan dunia Muslim lainnya, dengan mengambil contoh kasus Turki dan Mesir. Di dua Negara Muslim ini, pendidikan tradisional Islam umumnya terdiri dari tiga jenis, yaitu madrasah, kuttab dan masjid. Namun, di abad XX pendidikan tradisional di Turki lenyap ketika Kamal Ataturk menghapuskan sistem medresse (madrasah) dan merubahnya menjadi sekolah-sekolah umum, sedang di Mesir pendidikan kuttâb dan madrasah telah dihapuskan pada masa presiden Gamal Abdel Nasser pada tahun 1961 dan menggantinya dengan pendidikan nasional ala Barat. ${ }^{11}$

Tentang asal-usul tradisi pesantren, menurut Martin van Bruinessen, masih terdapat paradoks. Di satu sisi ia berakar kuat di bumi Indonesia; pondok pesantren bisa dianggap lembaga yang khas Indonesia. Meskipun ia merupakan lembaga pendidikan Islam tradisional, namun dalam beberapa aspek, berbeda dengan sekolah tradisional di dunia Islam mana pun. Di sisi lain, pada saat yang sama ia berorientasi internasional, dengan Makkah sebagai pusat

${ }^{9}$ Manfred Ziemek, Pesantren dalam Perubahan Sosial, terj. Butche B. Soendjojo, (Jakarta: P3M, 1986), h. 1.

${ }^{10}$ Azyumardi Azra, Pesantren: Kontinuitas dan Perubahan, dalam Nurcholish Madjid, Bilik-Bilik Pesantren Sebuah Potret Perjalanan, (Jakarta: Dian Rakyat, t.th.), h. xi.

${ }^{11}$ Azyumardi Azra, Pesantren: Kontinuitas..., h. xii-xiii. orientasinya, bukan Indonesia. ${ }^{12}$ Tradisi kitab kuning, jelas bukan berasal dari Indonesia. Semua kitab klasik yang dipelajari di Indonesia berbahasa Arab, dan sebagian besar ditulis sebelum Islam tersebar di Indonesia. Demikian juga, banyak kitab syarah atas teks klasik yang bukan berasal dari Indonesia (meskipun jumlah syarah yang ditulis ulama Indonesia makin banyak). ${ }^{13}$ Meskipun demikian, pada masa awal perkembangan Islam di Indonesia, banyak kitab karya ulama Indonesia yang ditulis dalam huruf Jawi. Huruf Jawi merupakan adaptasi dari huruf Arab untuk menuliskan lafaz-lafaz atau kalimat melayu. Salah satu contoh karya yang ditulis dalam bahasa Jawi (Arab Pegon) adalah kitab shirâth al-Mustaqîm, karya Nuruddin al-Raniri. ${ }^{14}$ Oleh karena itu, Nurcholish Madjid menyebut pesantren sebagai lembaga pendidikan yang tidak hanya identik dengan makna keislaman, tetapi juga mengandung makna keaslian Indonesia (indigenous). Sebab, lembaga yang serupa pesantren ini sebenarnya sudah ada sejak masa kekuasaan Hindu-Buddha. Sehingga Islam tinggal meneruskan dan mengislamkan lembaga pendidikan yang sudah ada. Tentunya hal ini tidak berarti mengecilkan peranan Islam dalam mempelopori pendidikan di Indonesia. ${ }^{15}$

Jika ditelusuri lebih jauh, akar tradisi keilmuan pesantren sesungguhnya dapat dilacak pada masyarakat Islam yang pertama. Salah satu watak utama dari Islam adalah tekanan yang berat sekali pada aspek pendidikan, sebagaimana dapat dilihat pada sejumlah sumber motivatif, seperti ayat-ayat Alquran dan hadis yang menggambarkan pentingnya arti ilmu bagi Islam dalam pandangan Allah dan Rasul. Atas dasar itulah, maka Islam mengembangkan perangkat keilmuannya sendiri sejak masa dini dari sejarahnya yang panjang, terbukti dengan adanya kelompok-kelompok yang telah

\footnotetext{
12 Martin van Bruinessen, Kitab Kuning, Pesantren dan Tarekat, (Yogyakarta: Gading Publishing, 2012), h. 89-90.

Martin van Bruinessen, Kitab Kuning..., h. 90.

Nor Huda, Islam Nusantara Sejarah Sosial Intelektual Islam di Indonesia, (Yogyakarta: Ar-Ruzz Media, 2007), h. 319.

15 Nurcholish Madjid, Bilik-Bilik Pesantren Sebuah Potret Perjalanan, (Jakarta: Dian Rakyat, t.th.), h. 3.
} 
melakukan spesialisasi, seperti ahli penafsir Alquran, ahli fikih, ahli bahasa dan sastra Arab dan lain sebagainya. ${ }^{16}$ Ilmu-ilmu tersebut semakin berkembang dari generasi ke generasi dan membentuk berbagai disiplin ilmu yang mandiri yang masih berkembang hingga saat ini. Ilmu-ilmu tersebut secara konsisten dan turuntemurun diajarkan di pesantren yang merupakan lembaga pendidikan Islam tradisional yang mampu berdiri kokoh di tengah terpaan sistem pendidikan Barat.

Singkat kata, pendidikan pesantren sesungguhnya merupakan perpaduan dari sistem pendidikan Islam yang berkembang di Timur Tengah dan telah memperoleh unsur-unsur serapan dari budaya lokal, terutama budaya Hindu-Bhudda yang telah lebih dulu berkembang di Indonesia. Unsur-unsur budaya lokal inilah yang memberikan citra dan cita rasa pada pendidikan pesantren sebagai pendidikan yang tumbuh dan lahir dari dalam rahim ibu pertiwi, sehingga memiliki kekebalan terhadap sistem pendidikan Barat.

\section{Bentuk-Bentuk Kitab Kuning}

Kitab kuning (kitab turâts) secara umum dipahami sebagai kitab-kitab keagamaan berbahasa Arab, atau berhuruf Arab sebagai produk pemikiran ulama pada masa lampau (salaf) yang ditulis dengan format khas pra modern, sebelum abad ke 17-an M. secara lebih rinci definisi tersebut dapat dijelaskan bahwa yang termasuk kitab kuning ialah kitab-kitab yang: (a) ditulis oleh ulama-ulama asing, tetapi secara turuntemurun menjadi referensi yang dipedomani oleh ulama Indonesia, (b) ditulis oleh ulama Indonesia sebagai karya 'independen' dan, (c) ditulis oleh ulama Indonesia sebagai komentar atau terjemahan atas karya-karya ulama asing. ${ }^{17}$ Dari segi bentuknya kitab-kitab tersebut meliputi:

\footnotetext{
${ }^{16}$ Abdurrahman Wahid, Islam Kosmopolitan...., h. 122.

${ }^{17}$ Affandi Mochtar, Kitab Kuning...., h. 32-33.
}

\section{Matan}

Kitab kuning atau kitab turâts memiliki beberapa bentuk yang berkembang dari satu waktu ke waktu yang lain. Kitab-kitab tersebut ada yang berbentuk matan, syarah, hâsyiyah, hâmisy, ta'lîqât, mukhtashar, khulâshah, taqrîrât dan ta $\underline{\text { qîq }}$. Pada awalnya, kita mengenal kitab-kitab turâts ditulis dalam bentuk matan. Matan adalah teks asli yang ditulis oleh seorang pengarang yang bukan merupakan penjelasan (syarah) dari kitab yang ditulis ulama lain. Kitab-kitab tersebut umumnya ringkas dan sederhana, seperti kitab Matan al-Ghâyah wa at-Taqrîb karya Imam Abu Sujâ'18, dan matan Qurrah al-'Ain bi Muhimmat al-Din karya Syekh Zain ad-Dîn al-Malîbâri. Tradisi penulisan kitab matan ini berlangsung lama, dari abad pertama hijriyah sampai fase kedua kemunduran pemikiran Islam pada abad ketujuh hijriyah dan berlanjut sampai sekarang.

\section{Syarah}

Syarah adalah kitab yang ditulis sebagai komentar atau penjelasan dari kitab yang ditulis oleh ulama lain. ${ }^{19}$ Dalam kitab syarah, semua kata atau frasa yang terdapat pada kitab matan diberi penjelasan, baik menyangkut aspek bahasa maupun aspek makna. Kitab syarah ada yang sederhana, seperti Sullam al-Munâjâh, syarah dari Safinah al-Shalâh ${ }^{20}$ dan ada juga yang besar, seperti kitab al-Majmû', syarah dari kitab al-Muhazzab. Syarah biasanya dilakukan oleh ulama lain, seperti kitab Matan al-Ghâyah wa at-Taqrîb karya Abu Syuja’ yang disyarahkan menjadi kitab Fath al-Qarîb, karya Ibnu Qasim al-Ghuzzi. ${ }^{21}$ Tetapi ada juga kitab matan yang

${ }^{18}$ Kitab ini diberi syarah oleh al-Allamah Abu Abd Allah Muhammad bin Qasim al-Ghuzzi al-Syafi'i dengan judul Fath al-Qarîb al-Mujîb fì Syarah Alfàz al-Taqrîb.

${ }^{19}$ Affandi Mochtar, Kitab Kuning sebuah Observasi Umum, dalam Marzuki Wahid, dkk., Pesantren Masa Depan Wacana Pemberdayaan dan Transformasi Pesantren, (Bandung: Pustaka Hidayah, 1999), h. 223.

20 Kitab Safinah al-Shalâh merupakan risalah pendek tentang shalat, karya Sayyid Abd Allah al-Hadhrami Ibn Umar yang diberi syarah oleh Syekh Muhammad Nawawi al-Bantani dengan judul Syarah Sullam al-Munâjâh. Kitab syarah ini berbentuk korasan dan hanya terdiri dari 28 halaman.

${ }^{21}$ Kedua kitab ini sangat populer dan menjadi kitab yang 
disyarahkan oleh penulisnya sendiri, seperti kitab Qurrah al-Ain bi Muhimmât al-Dîn dan syarahnya, Fath al-Muîn karya Zainuddin alMalibari.

Tradisi penulisan syarah berawal dari kemandekan aktivitas ijtihad yang mulai terjadi pada pertengahan abad keempat hijriyah dan mencapai puncaknya ketika Baghdad jatuh ke tangan Hulagu Khan dan berlanjut sampai sekarang. ${ }^{22}$ Pada masa lalu, penulisan syarah hanya berkisar pada kitab dalam satu mazhab, namun saat ini banyak pensyarah yang mensyarahkan kitab dari mazhab lain. Dalam kegiatan pensyarahan, seorang pensyarah juga sering kali mengutip pendapat dari mazhab lain, meskipun, posisinya hanya sebatas informasi tambahan atau informasi pembanding dan seringkali dimaksudkan untuk menunjukkan bahwa dalam persoalan yang dibahas tersebut terdapat perbedaan pendapat di antara ulama mazhab. ${ }^{23}$

\section{Hasyiyah, hamisy, ta'liqat}

Hâsyizah adalah komentar atas kitab syarah yang masih memerlukan penjelasan lanjutan. Berbeda dengan syarah, hâsyiyah tidak memberikan penjelasan terhadap seluruh kata

wajib diajarkan di pesantren-pesantren salaf seluruh Indonesia.

${ }^{22}$ Sebagai bukti bahwa tradisi syarah masih berlanjut sampai sekarang adalah apa yang terjadi pada kitab al-Waraqât, karya Imam al-Haramain al-Juwaini. Kitab ushul fikih yang sederhana ini diberi syarah oleh ulama salaf dan khalaf. Di antara syarahnya adalah: (a) Syarah al-Waraqât, karya Jalal al-Din al-Mahalli, (b) Syarah al-Waraqât karya Syekh Abd Allah al-Fauzan, (c) Syarah al-Waraqât karya Khalid al-Shaq'abi, (d) Syarah al-Waraqât karya Syekh Shalih bin Abd al-Aziz Alu al-Syeikh, dan (e) Syarah al-waraqât karya Muhammad al-Hasan al-Didu al-Syanqithi. Dan juga kitab al-Bayân al-Mulammi' 'an Bayân al-Luma', karya Kiai Sahal Mahfuz Kajen. Kitab ini merupakan syarah dari kitab al-Luma', karya Abu Ishaq al-Syairazi.

23 Sebagai contoh Imam al-Syarbini dalam kitab al-Iqnâ' menyebutkan satu keterangan tentang hukum tatslits, تثيث, dalam berwudhu'. Menurutnya, تثليث itu hukumnya sunnah, baik dalam membasuh, mengusap, menyela-nyela anggota wudhu', baik yang sunnah maupun yang wajib. Imam alSyarbini lalu memberikan catatan bahwa mushannif (pengarang kitab matan Abî Syujâ) tidak membahas tentang hukum menتثليث -kan bacaan-bacaan sunnah dalam wudhu' seperti membaca tasmiyah, dan tasyahhud di akhir wudhu', apakah disunnahkan atau tidak? Dalam hal ini, al-Syarbini mengutip pendapat Imam Ahmad bin Hanbal yang menyatakan bahwa membaca tasyahhud (do'a) setelah wudhu' sunnah dilakukan tiga kali. (alSyarbini, al-Iqnầ fî Hall Alfàz Abî Syujầ, juz 1, h. 50). atau frasa yang terdapat dalam kitab yang dihâsyiyah-kan, tetapi hanya menjelaskan kata atau frasa tertentu yang dipandang memerlukan penjelasan lebih detil. Hâsyiyah umumnya diletakkan di dalam garis margin yang berbentuk segi empat, sedang kitab yang diberi hâsyiyah diletak di pinggir kiri atau kanan garis. Salah satu kitab hâsyiyah yang banyak beredar di pesantren ialah hâsyiyah al-Bajuri, karya Syekh Ibrahim al-Bajuri. Kitab ini merupakan komentar terhadap kitab (syarah) Fath alQarîb al-Mujîb, karya Ibn Qasim al-Ghuzzi. Kitab yang di-hâsyiyah-kan biasanya ditulis di pinggir kitab (hâmisy). Kitab hâmisy umumnya berupa catatan yang diletakkan di pinggir kiri dan kanan kitab. Komentar dalam kitab hâmisy, seperti halnya ta'lîqât, biasanya berupa catatancatatan pendek yang dipandang penting. Salah satu kitab ta’lîqât, yang cukup populer adalah kitab al-Mankhûl min Tálîqât, al-Ushûl karya alGhazali. Kitab ini merupakan kumpulan catatan al-Ghazali terhadap kuliah yang diberikan oleh gurunya, Imam al-Juwainy.

Contoh kitab matan, syarah dan hasyiyah adalah apa yang terdapat pada kitab Qurrah al-Ain bi Muhimmât ad-Dîn, yang kemudian disyarahkan dengan nama Fath al-Muîn dan dihasyiyahkan dengan kitab I'ânah at-Thâlibîn berikut:

Matan Taqrib:

$$
\text { ويؤمر مميز بها لسبع ويضرب عليها لعشر. }
$$

Syarah Fath al-Qarib:

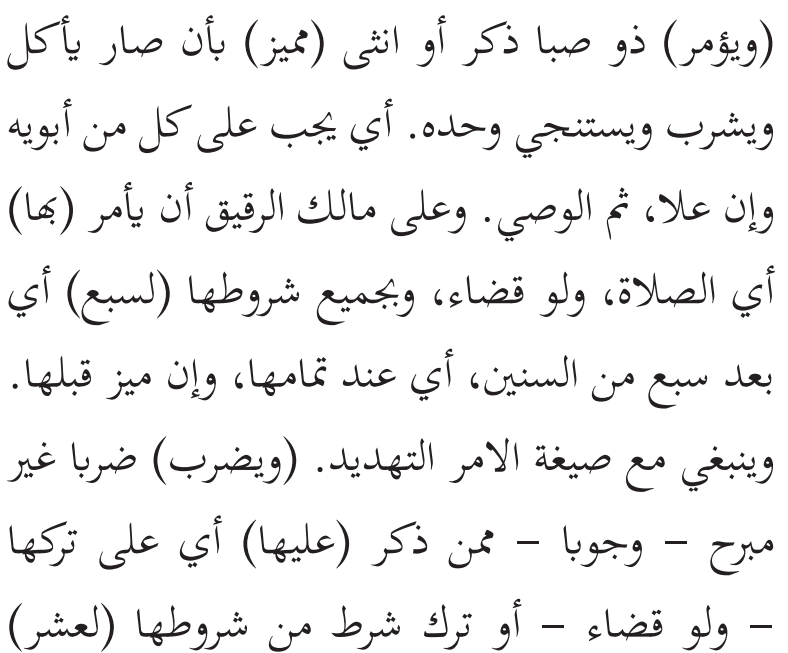




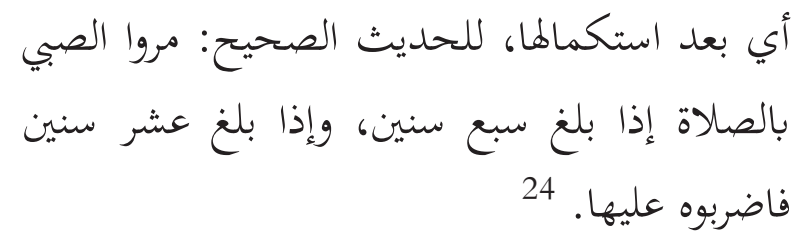

Hasyiyah I'anah at-Thalibin:

(قوله: بأن صار يأكل إلخ) هذا أحسن ما قيل في

ضابط المميز. وقيل: أن يعرف يمينه من شماله. وقيل: أن يفهم الخطاب ويرد الجواب. والمراد بمعرفة يمينه من ين ئن شماله معرفة ما يضره وينفعه. ويوافق التفسير الثاني خبر أبي دواد أنه (ص) سئل: متى يؤمر الصبي بالصلاة ؟ فقال: إذاعرف يمينه من شماله. أي ما يضره محا ينفعه. اه ع ش بتصرف. (قوله: أي يجب على كل من أبويه وإن علا) أي ولو من جهة الام. والوجوب كفائي فيسقط بفعل أحدها: لانه من الامر بالمعروف، ولذا خوطبت به الام ولا ولاية لها. (قوله: التهديد) أي إن احتيج إليه. اه سم. (قوله: غير مبرح) بكسر الراء المشددة، أي مؤلم. قال ع ش: أي وإن كثر. خلافا لما نقل عن ابن سريج من أنه لا يضرب فوق ثلاث ضربات، أخذا من حديث: غط جبريل للنبي (ص) ثلاث مرات في ابتداء الوحي. اه. ولو لم يفد إلا المبرح تركهما وفاقا لابن عبد السلام، وخلافا لقول البلقيني: يفعل غير المبرح كالحد.

Contoh di atas memperlihatkan bahwa dari matan yang hanya setengah baris di-syarahkan menjadi lima baris dan di-hâsyiyah-kan menjadi delapan baris. Dari sini juga terlihat bahwa dalam hâsyizah tidak semua kata atau frasa diberi komentar atau penjelasan. Penulis hâsyiyah hanya mengomentari kata atau frasa

${ }^{24}$ Zain al-Din bin Abd al-Aziz al-Malibari, Fath al-Muîn li Syarah Qurrah al-Ain bi Muhimmâtal-Dîn, (Beirut: Dar al-Fikr, t.th.), h. 24 .

${ }^{25}$ Al-Sayyid Bakri ibn al-'Arif bi Allah al-Sayyid Muhammad Syatha al-Dimyathi, I'ânah al-Thâlibîn, (Semarang: Toha Putra, t.th.), juz 1, h. 24. tertentu yang menurut pandangannya perlu diberi komentar atau penjelasan.

\section{Khulashah, Mukhtashar, Mujaz}

Mukhtashar ialah sebuah karya yang ringkas, tetapi padat isinya. ${ }^{26}$ Kata ini berdekatan maknanya dengan kata khulâshah, dan îjaz atau mûjaz. Ada juga yang berpendapat bahwa khulàshah adalah sebuah karya yang singkat, bisa jadi isinya padat, sedikit ataupun seimbang antara lafaz dan maknanya. ${ }^{27}$ Pada umumnya kitab mukhtashar merupakan karya ringkasan dari kitab lain yang lebih panjang. Misalnya, kitab Mukhtashar Ihyâ' Ulûm al-Dîn yang diberi nama Lubâb al-Ihyâ. Keduanya adalah karya Hujjah al-Islâm Abu Hamid al-Ghazali. Namun, beberapa kitab mukhtashar disusun dari kuliahkuliah yang disampaikan oleh seorang ulama besar, kemudian materi perkuliahan tersebut diringkas dan dibukukan oleh muridnya. Salah satu kitab mukhtashar yang sangat terkenal adalah mukhtashar al-Muzani, karya Imam al-Muzani yang dihimpun dari ceramah-ceramah Imam alSyafi'i.

\section{Urgensi Kitab Syarah}

Dalam sejarah hukum Islam, tradisi penulisan syarah telah menghasilkan ribuan, bahkan jutaan kitab, baik yang sempat diterbitkan, maupun yang masih dalam bentuk manuskrip, baik yang masih terbit sampai hari ini, maupun yang sudah mengalami kepunahan. Banyaknya kitab syarah ini menunjukkan bahwa kebutuhan terhadap syarah amat besar. Hal ini disebabkan karena kitab matan yang ada tidak mampu memenuhi kebutuhan umat terhadap penjelasan hukum Islam yang lebih luas. Kebutuhan terhadap kitab syarah ini antara lain disebabkan oleh: (1) kemahiran seorang pengarang dalam menampilkan redaksi sehingga ia mampu memaparkan pengertian yang men-

\footnotetext{
${ }^{26}$ Syekh Nawawi al-Bantani, Qût al-Habîb al-Gharîb Taushîh alâ Fath al-Qarîb, (Indonesia: Al-Haramain, 2005), h. 5.

${ }^{27}$ Syekh Ibrahim al-Bajuri, Hâsyiyah al-Bâjûrî̀ 'alâ Ibn Qâsim al-Ghuzzî, (Semarang: Toha Putra, t.th.), juz 1, h. 18.
} 
dalam dengan bahasa yang amat singkat; (2) pengarang membuang suatu alasan karena dinilai telah jelas dengan sendirinya, dan penulis syarah merasa perlu memunculkan kembali alasan yang dibuang itu; (3) suatu pernyataan terkadang perlu ulasan tegas, karena pernyataan itu muncul dalam bahasa sindiran (majaz atau kinayah). ${ }^{28}$

Terlepas dari kenyataan sejarah bahwa tradisi penulisan kitab syarah berawal dari periode kemunduran fikih, penulisan syarah tidak sepenuhnya dapat dipersalahkan. Hal ini perlu ditegaskan, mengingat banyak kalangan yang menuduh syarah sebagai biang keladi kemunduran fikih. Padahal, ia hanya merupakan produk dari suatu periode dari periode-periode yang dilalui fikih. Yang menjadi ukuran bukanlah bentuk dari suatu kitab, apakah matan, syarah, hâsyizah atau lainnya, melainkan kualitas isi kitabnya. Sedang, kualitas isi kitab ditentukan oleh banyak hal, seperti orisinalitas gagasan, diskusi yang disajikan, gaya penyajian, konsistensi gagasan, ide-ide baru yang diangkat, serta sistematika pembahasan.

Bentuk kitab yang berbeda-beda (matan, syarah, hâsyiyah khulâshah, mukhtashar, atau lainnya) seharusnya tidak dilihat sebagai pembeda atau penanda kemajuan atau kemunduran pemikiran dalam Islam, tetapi harus dilihat dari kacamata penjenjangan dalam proses pendidikan. Hal ini sebagaimana diisyaratkan oleh Syekh Nawawi Banten. Ia menganjurkan agar setiap orang memulai pelajarannya dengan mempelajari kitab matan. Setelah menguasai kitab matan, barulah ia mempelajari kitabkitab syarah. ${ }^{29}$ Dan setelah mampu memahami kitab syarah, barulah ia membaca kitab hâsyiyah. Dengan penjenjangan seperti ini, struktur pemahaman seseorang akan tersistematisasi secara baik, diawali dari pengetahuan yang bersifat dasar, kemudian dilanjutkan kepada yang

${ }^{28}$ Chozin Nasuha, Epistemologi Kitab Kuning, dalam Marzuki Wahid, dkk., Pesantren Masa Depan Wacana Pemberdayaan dan Transformasi Pesantren, (Bandung: Pustaka Hidayah, 1999), h. 263.

${ }_{29}$ Syekh Nawawi al-Bantani, Salalim al-Fudhalà', (Pilang Wetan: Pesantren Hidayatul Mubtadi'in, t. th), h. 91. lebih luas dan yang lebih luas lagi. Dengan demikian, seorang pelajar/santri akan memiliki pemahaman yang benar dan utuh terhadap kitab-kitab yang dipelajari sesuai perkembangan usianya.

Terlepas dari stigma yang disematkan pada kitab syarah, ia memiliki beberapa keistimewaan, yaitu:

1. Syarah menyediakan penjelasan yang panjang lebar dan detil dari suatu persoalan yang didiskusikan. Kitab-kitab dalam bentuk matan, baik yang berupa nazhm, maupun natsr, umumnya adalah kitab-kitab yang pendek dan sederhana. Karena pendek, terkadang maksud yang dikehendaki oleh penulis kitab sulit untuk dicerna dan dipahami oleh orang lain, khususnya para pembaca ghair al-nâthiqîn bi al-Arabiyyah (bukan pengguna bahasa Arab) atau orang-orang non-Arab. Karena penjelasan yang diberikan terlalu singkat, seringkali membingungkan pembaca atau menimbulkan tanda tanya baru yang belum dijelaskan oleh kitab yang disyarahkan tersebut. Kitab yang dalam bentuk nazhm umumnya lebih sulit lagi dipahami, sebab Nâzhim (penyusun kitab nazhm) terikat oleh kaidah-kaidah nazhm yang sering memaksanya mendahulukan kata yang seharusnya diakhirkan atau sebaliknya, menambah atau mengurang lafaz, mengîjaz-kan kalimat, merubah struktur kalimat dan lain sebagainya. Hal ini menyebabkan kesulitan dalam memahami isi kitab tersebut semakin bertambah. Dengan hadirnya kitabkitab syarah, pembaca akan memperoleh penjelasan yang dibutuhkannya dengan cara yang lebih mudah. ${ }^{30}$

2. Syarah membantu para pembaca memperkaya kosa kata dalam bahasa Arab. Kekayaan terhadap penguasaan kosa kata dalam bahasa Arab sangat membantu pemahaman pembaca. Kitab-kitab syarah menyediakan kosa kata yang lebih banyak bagi para

${ }^{30}$ Muhammad Dasuqy, Muqaddimah fî Dirâsah al-Figh alIslâmy, (Qatar: Dar al-Tsaqafah, 2004), h. 196. 
pembacanya. ${ }^{31}$ Dalam kaitan ini, ada dua metode yang umum digunakan oleh para Syârih (pensyarah kitab), yaitu metode ijmâli dan metode tahlîli. Metode ijmâli dilakukan dengan menjelaskan setiap kata yang terdapat dalam kitab yang disyarabkan dengan cara menyebutkan kata-kata yang semakna (murâdif), atau menjelaskan lawan kata dari kata yang di-syarah-kan. Kata yang disyarabkan/dijelaskan pengertiannya diletakkan di dalam kurung baru diikuti oleh kata yang mensyarah, yang umumnya dihubungkan dengan kata $s$, yang artinya 'maksudnya'. Metode ijmali hanya menyajikan informasi tambahan singkat, tetapi banyak membantu pengayaan kosa kata dan pemahaman terhadap teks yang disyarahkan. Sedang metode tahlîlî ialah menjelaskan makna kosa kata, frasa atau kalimat dengan penjelasan lebih luas dan panjang lebar. Dalam metode ini, makna kosa kata tetap diperhatikan, bahkan penjelasan aspek yang terkait aspek kebahasaan juga lebih lengkap. Namun, perhatian terhadap penjelasan makna, maka uraian yang disajikan oleh Syârih sangat panjang dan sangat luas. Bisa saja satu kata disyarahkan dengan beberapa halaman sesuai dengan tema/topik yang dibahas dalam kitab yang disyarahkan. Pada metode yang kedua ini yang ditekankan adalah keluasan pemahaman terhadap topik yang dibicarakan, bukan pada makna literal dari suatu kata. Karena itu, metode ini sangat membantu para pembaca memperluas cakrawala pemahaman terhadap suatu topik.

3. Syarah menggambarkan terjalinnya jaringan keilmuan seorang pengarang dengan guru atau pengarang kitab yang disyarabkan serta mempererat hubungan emosional antara keduanya. Keterjalinan emosional antara murid dan guru, baik secara langsung atau tidak merupakan hal penting dalam tradisi

31 Wawancara dengan KH. Abdul Ghafur Pimpinan Pondok Pesantren Al-Anwar 3 Sarang Rembang Jawa Tengah pada tanggal 4 Pebruari 2015 jam 19.25-18.15 WIB. pensyarahan kitab. Seorang (syârih) pensyarah mestilah memiliki hubungan emosional yang baik dengan pengarang kitab yang di-syarahkannya. Hubungan emosional yang baik ini dalam dimensi ahlak memiliki nilai penting. Sebab, pensyarahan kitab merupakan kegiatan akademik yang memiliki dimensi ibadah. Seorang pensyarah kitab berharap dengan karyanya itu agar apa yang dikarang oleh ulama pendahulunya lebih memberikan manfaat melalui kegiatan pensyarahan ini. Dengan demikian, kedua penyusun kitab tersebut memperoleh kebaikan dari apa yang dilakukan oleh pensyarah. Dengan kegiatan pensyarahan ini hubungan batin antara pengarang kitab pertama dan pensyarahnya terjalin secara mesra. ${ }^{32}$

4. Syarah melestarikan eksistensi mazhab dan tradisi bermazhab. Tradisi penulisan kitab, sebagaimana disebutkan di muka, lahir dari fase kemandekan pemikiran hukum Islam yang mulai terjadi pada pertengahan abad keempat dan diikuti dengan menguatnya pola bermazhab. Para ulama yang hidup pada masa itu mengikatkan diri pada mazhab ikutan masing-masing. Penulisan kitab diarahkan pada upaya mensyarah apa yang sudah ditulis oleh para imam mazhab atau murid-murid imam mazhab yang kenamaan. Kegiatan mensyarahkan kitabkitab mazhab ini berperan besar dalam menyebarluaskan ajaran para imam mazhab. Tersebar luasnya ajaran imam mazhab ini membuat mazhab yang diikutinya semakin besar dan memiliki banyak pengikut. Para pengikut mazhab ini pada gilirannya akan membela dan mempertahankan mazhab ikutannya dari segala bentuk ancaman yang dapat melemahkan eksistensinya. ${ }^{33}$ Oleh

32 Hubungan emosional seperti ini juga terjalin antara pengarang kitab, guru dan santri. Seorang guru mengaji (kiai) tidak lupa membacakan fatihah untuk pengarang kitab yang dibaca sebelum pembacaan kita dimulai. Pembacaan fatihah juga dihadiahkan kepada guru yang mengajarkan kitab tersebut kepada pembaca kitab, sehingga terjalin hubungan batin yang harmonis antar santri, guru dan pengarang kitab.

${ }^{33}$ Wawancara dengan KH. Abdul Ghafur Pimpinan Pondok 
karena itu, mazhab yang tidak mendapatkan pengikut akan mengalami kematian dan kepunahan.

5. Kitab syarah memberikan argumentasi pada setiap tahap detil pembahasan suatu masalah. Suatu masalah sederhana yang disajikan kitab matan pada umumnya tidak menyertakan landasan normatif (dalil, argumentasi logis) bagi masalah yang disajikan. Ia hanya memberikan penjelasan singkat seperlunya, sifatnya hanya primary information. Dalam kaitan ini, kitab-kitab syarah memberikan penjelasan panjang lebar disertai dengan landasan normatif yang menjadi dasar penetapan hukum masalah-masalah tersebut. Misalnya, dalam matan Safinah al-Najâ dijelaskan bahwa rukun shalat yang terakhir adalah mengucapkan salam, dengan sekurang-kurangnya mengucapkan السلام عليكم. Keterangan ini tidak dilengkapi dengan dalil atau argumentasi apapun. Juga tidak disertai penjelasan tentang redaksi salam yang lengkap. ${ }^{34}$

Dalam syarah kitab tersebut, Syekh Nawawi Banten menjelaskan bahwa keberadaan salam sebagai rukun shalat didasarkan pada hadis Nabi: ${ }^{35}$

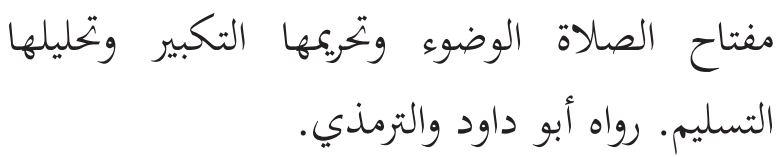

"Pembuka shalat adalah wudhu', pengharamnya adalah takbir dan penghalalnya adalah salam."

Adapun ungkapan salam yang lengkap adalah وبركاته Syekh Nawawi Banten Banten juga menambahkan penjelasan bahwa salam yang kedua itu sunnah hukumnya atas dasar اتباع (mengikut) kepada Nabi. ${ }^{36}$ Di sini Syekh Nawawi Banten Banten memberikan

Pesantren Al-Anwar 3 Sarang Rembang Jawa Tengah pada tanggal 4 Pebruari 2015 jam 19.25-18.15 WIB.

${ }^{34}$ Salim bin Samir al-Hadhrami, Matn Safinah al-Najâ, (alMaktabah al-Syâmilah edisi 53 GB, versi 3.44), h. 5.

${ }^{35}$ Syekh Nawawi al-Bantani, Kâsyifah al-Sajà Syarah Safinah al-Najâ, (Surabaya: Maktabah Syekh Muhammad bin Ahmad Nabhan wa Auladih, t.th.), h. 62.

${ }^{36}$ Ibid. penjelasan tambahan sambil menghadirkan dalil yang dijadikan dasar penetapan hukum tersebut. Selanjutnya, dalam shalat berjama'ah apabila imam tidak melaksanakan salam yang kedua, makmum disunnahkan melakukan salam kedua tersebut. Dalam hal ini, shalat makmum tidak menjadi batal, karena ia telah selesai melakukan mutâba'ah (pengikutan kepada imam) dengan telah selesainya salam yang pertama. Hal ini berbeda dengan masalah tasyahhud awwal. Apabila imam tidak melakukan tasyahhud awwal, maka makmum wajib meninggalkannya untuk mengikuti imam, sebab ia wajib mutâbảah kepada imam selagi belum salam yang pertama. Makmum seyogyanya melakukan salam setelah salam imam, jika berbarengan, makruh hukumnya.

Syekh Nawawi Banten juga menambahkan penjelasan tentang apa yang seyogyanya dilakukan setelah salam yang kedua. Menurutnya, setelah salam kedua disunnahkan duduk untuk berzikir dan berdo'a. Berzikir setelah shalat dapat melembutkan hati, berdo'a setelah shalat dikabulkan Allah. Setelah shalat, Nabi membaca istighfar 3 kali, lalu membaca:

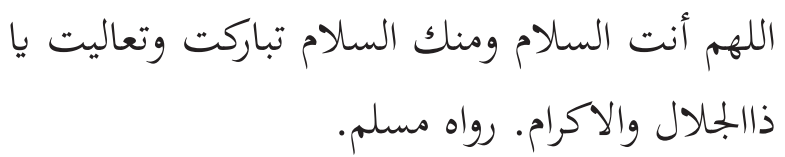

Kemudian membaca:

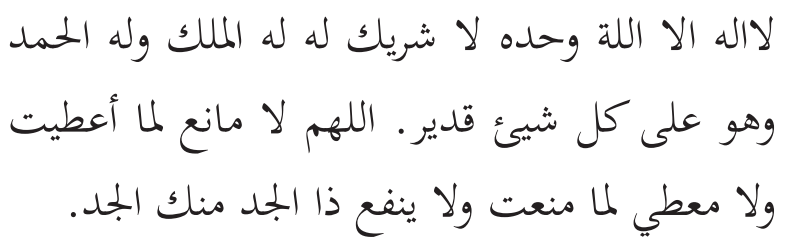

Setelah itu, Nabi membaca tasbih sebanyak 33 kali, tahmid sebanyak 33 kali dan takbir sebanyak 33 kali. Penjelasan ini didasarkan pada hadis Nabi: ${ }^{37}$

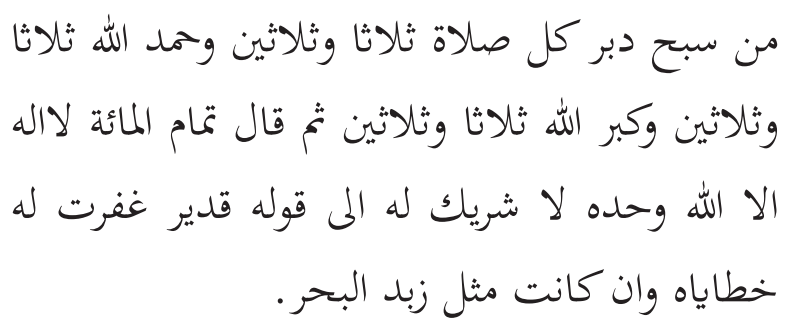

${ }^{37}$ Syekh Nawawi al-Bantani, Kâsyifah...., h. 62. 
Setelah selesai berzikir disunnahkan membaca do'a. Hal ini didasarkan pada hadis Nabi:

$$
\begin{aligned}
& \text { سئل النبي صلى الله عليه وسلم أي الدعاء أسمع؟ أى } \\
& \text { أقرب الى الاجابة, قال: جوف الليل و دبر الصلوات } \\
& \text { المكتوبات. رواه الترمذي. }
\end{aligned}
$$

Ia juga menjelaskan bahwa semua zikir dan do'a tersebut disunnahkan dengan suara lirih. Namun boleh mengeraskannya apabila ada maksud dari imam untuk mengajari para makmum. ${ }^{38}$

Meskipun kitab syarah atau hâsyiyah memiliki kelebihan dalam hal penjelasan yang diberikan, namun ia juga mengandung beberapa kelemahan, antara lain:

1. Uraian panjang lebar yang diberikan kitab syarh atau hâsyiyah seringkali memasukkan berbagai aspek, baik yang terkait tata bahasa, sastra, filsafat, dan sebagainya sehingga dapat mengaburkan maksud sebenarnya yang ingin disampaikan penulis.

2. Kitab syarah atau hâsyiyah seringkali merupakan karya yang sangat besar, berjilidjilid dan beribu halaman. Ini menyebabkan kesulitan bagi para pembaca untuk mengkhatamkan kitab tersebut dalam jangka waktu tertentu. Untuk dapat membacanya secara utuh iseseorang memerlukan waktu yang sangat panjang.

3. Kitab syarah atau hâsyiyah membuat para santri lama berkutat dalam bab-bab tertentu dari kitab matan dan kitab syarah atau hâsyiyah-nya. Dari sini terjadi pengulangan materi yang sama secara bertingkat dari matan, syarah baru ke hâsyiyah. Kalau seorang santri belajar matan Ghâyah wa al-Taqrîb pada tingkat dasar, lalu diajarkan syarahnya (Fath al-qarîb) pada jenjang Tsanawiyah dan diajarkan hâsyiyah al-Bâjûrî pada tingkat Aliyah, maka sesungguhnya ia belum beranjak dari obyek yang sudah dipelajarinya saat berada di jenjang sekolah dasar.

${ }^{38}$ Ibid., h. 62.

\section{Eksistensi Kitab Syarah di Pesantren}

Sebagian besar kitab kuning yang diajarkan di pesantren merupakan kitab syarah, sejak syarah yang sederhana hingga syarah yang besar dan terdiri dari berjilid-jilid. Mayoritas kitab syarah tersebut merupakan kitab-kitab fikih Syafi'iyyah. Dominasi kitab fikih Syafi'iyyah ini berlangsung selama berabad-abad, sampai sekarang. ${ }^{39}$ Menurut penelitian Martin van Bruinessen, seperti dikutip Affandi Mochtar, bahwa kitab-kitab fikih Syafi'iyyah berasal atau merupakan kreasi lanjutan dari tiga kitab kuning pendahulunya yang berbentuk matan. Ketiga kitab tersebut adalah: kitab al-Muharrar karya al-Rofi'i (w.625 H/1226 M), kitab Matan Ghâyah wa al-Taqrîb karya Abu Syuja' al-Isfahani (w. 593 H/1197 M), dan kitab Qurrah al-Ain karya al-Malibari (w. 975 H/1567 M). Ketiga kitab kuning ini masing-masing membuat garis perkembangan sejumlah kitab kuning tersendiri setelahnya. ${ }^{40}$

Dari garis kitab al-Muharrar, muncul kitab Minhâj al-Thâlibîn karya al-Nawawi, lalu syarah Minhâj, yaitu Tuhfah al-Muhtâj karya Ibnu Hajar al-Haitami, dan kitab Nihâyah al-Muhtâj karya al-Ramli, al-Mughnî al-Muhtâj karya al-Khatib al-Syarbini, kitab al-Mahallî karya Syams al-Dîn al-Mahalli dan kitab Minhâj al-Thullâb karya Zakaria al-Anshari. Dari Minhâj al-Thullâb, lahir kitab fath al-Wahhâb karya al-Anshari, dan dari Fath al-Wahhâb, lahir dua hâsyiyah, yaitu Hâsyiyah al-Bujairimi dan Hâsyiyah al-Jamal. Dari garis kitab Matn al-Ghâyah wa al-Taqrîb muncul kitab al-Iqnâ'karya al-Syarbini, Kifâyah al-Akhyâr karya al-Dimasyqi, Fath al-Qarîb al-Mujîb karya Ibnu Qasim al-Ghuzzi. Dari kitab fath al-Qarîb lahir kitab al-Bâjûri karya Ibrahim al-Bajuri dan kitab Qût al-Habîb alGharîb yang terkenal dengan sebutan Tausyîh

39 Dominasi kitab-kitab fikih Syafi'iyyah ini dapat dimaklumi, mengingat para pembawa Islam ke Indonesia adalah para ulama mazhab Syafi'i. Hingga abad ke XXI, dominasi ini masih sangat terasa, meskipun para ulama pesantren mulai memberi ruang untuk kitab-kitab mazhab lain, bahkan kitabkitab fikih non-mazhab (fiqh Aamm) untuk diajarkan dan dijadikan referensi dalam penetapan hukum.

${ }^{40}$ Affandi Mochtar, Kitab Kuning...., h. 67. 
'alâ Ibn Qâsim al-Ghuzzî karya Syekh Nawawi al-Bantani. Sedang dari garis Qurrah al-Ain lahir kitab Nihâyah al-Zein karya Syekh Nawawi al-Bantani dan kitab Fath al-Muîn karya alMalibari. Sedang dari kitab Fath al-Mu'in lahir kitah I'ânah al-Thâlibîn karya Sayyid Bakri dan kitab Tarsyîh al-Mustafîdîn karya 'Almi alSaqqaf. ${ }^{41}$

Kitab-kitab lain yang diajarkan dan popular di pesantren adalah kitab Sullam al-Taufiq karya Syekh Abdullah bin al-Husain bin Thahir bin Muhammad bin Hasyim Ba'alawi. Dari garis kitab ini lahir kitab Mirqât Shu'ûd al-Tashdîq karya Syekh Nawawi al-Bantani. Kitab lain yang juga popular di pesantren adalah kitab Muqaddimah Hadhramiyyah karya Abdullah bin Abdul Karim Ba-Fadhal. Dari kitab ini lahir kitab Minhâj al-Qawîm karya Ibnu Hajar, yang kemudian dihâsyiyahkan menjadi kitab alHawâsyî al-Madaniyyah karya Muhammad bin Sulaiman al-Kurdi.

Kitab-kitab tersebut diajarkan di pesantren salaf Indonesia dari masa ke masa sampai hari ini. Tidak hanya dijadikan bahan ajar, kitab-kitab tersebut juga dijadikan rujukan/ dasar dalam penetapan hukum oleh Lembaga Bahsul masail yang merupakan lembaga fatwa di bawah naungan Nahdlatul Ulama. Dari sekitar lima ratus fatwa yang dikeluarkan oleh Lembaga Bahsul Masail NU, sebagian besarnya ditetapkan berdasarkan referensi kitab-kitab syarah. Hanya ada sedikit fatwa (terbaru) yang didasarkan langsung kepada Alquran dan Hadis. Sebab, dalam tradisi yang berkembang di dalam Lembaga Bahsul Masail, metode yang paling banyak diikuti adalah metode bermazhab secara qauli, yaitu dengan mengikuti pendapat para ulama mazhab secara langsung. Tradisi ini memberikan kontribusi besar terhadap pelestarian kitab kuning yang mayoritasnya terdiri dari kitab syarah.

${ }^{41}$ Affandi Mochtar, Kitab Kuning...., h. 67-69.

\section{Penulisan Kitab Syarah di Indonesia}

Secara umum, proses islamisasi Indonesia ditempuh melalui dua fase. Pertama; para pendakwah dari Arab datang ke Indonesia untuk menyebarkan Islam. Kedua; para pelajar Indonesia datang atau bermigrasi ke Makkah dan Madinah (Haramain) untuk belajar di sana dan kemudian kembali ke wilayah mereka masing-masing untuk mengajarkan ilmu agama. ${ }^{42}$ Di antara pelajar tersebut ada juga yang menetap (bermukim) di Makkah dan mengajar di sana sampai wafatnya. Mereka ini antara lain adalah Syekh Muhammad Nawawi al-Bantani, Syekh Mahfuz al-Tirmisi, Syekh Ahmad Khatib al-Minangkabawi dan Syekh Yasin al-Fadani.

Di samping mengajar, mereka juga menulis sejumlah kitab. Dari nama-nama tersebut Syekh Muhammad Nawawi al-Bantani dikenal sebagai ulama paling produktif. Menurut sebagian peneliti, ia menulis tidak kurang dari seratus buah kitab. Delapan belas kitabnya, hingga saat ini masih menjadi materi ajar di hampir seluruh pesantren salaf. Dalam tulisan ini, kajian akan difokuskan pada Syekh Muhammad Nawawi al-Bantani, yang merupakan guru intelektual pesantren. Ia menulis tidak kurang dalam sembilan bidang keilmuan, yaitu tafsir, fikih, ushuluddin, ilmu tauhid (teologi), tasawuf (mistisisme), kehidupan Nabi (sirah nabawiyah), tata bahasa Arab, hadis, dan akhlak (ajaran moral Islam).$^{43}$ Dari bidang-bidang yang ditulis oleh al-Bantani, penulis hanya akan menyoroti karya beliau dalam bidang fikih saja.

Setidaknya terdapat delapan karya Syekh Nawawi al-Bantani dalam bidang fikih yang diterbitkan dan dipelajari di berbagai pesantren Indonesia. Karya-karya tersebut mulai dari karya sederhana yang terdiri dari beberapa halaman, karya sedang yang terdiri kurang dari 100 halaman atau seratusan halaman dan karya yang terbilang besar terdiri dari 300 halaman

42 Azyumardi Azra, Jaringan Global dan Lokal Islam Nusantara, (Bandung: Mizan, t.th.), h. 63.

${ }^{43}$ Abdurrahman Mas'ud, Dari Haramain ke Nusantara Jejak Intelektual Arsitek Pesantren, (Jakarta: Kencana Prenada Media Group, 2006), h. 111. 
atau lebih. ${ }^{44}$ Karya fikih yang tergolong kecil adalah kitab Syarah Sullam al-Munâjât (28 halaman), Syarah 'Uqûd al-Lujain fî Bayân Huqûq az-Zaujain (22 halaman), dan Bahjah alWasầil bi Syarah al-Masầil (40 halaman). Yang sedang ada tiga kitab, yaitu kitab Syarah Sullam at-Taufiq atau yang nama lengkapnya 'Mirqât Shu'ûd at-Tashdîq fî Syarah Sullam at-Taufîq (88 halaman), Syarah ar-Riyâdh al-Badî'ah (96 halaman), dan Kâsyifah as-Sajâ Syarah Safinah al-Najâ (116 halaman). Sedang yang tergolong besar ada dua kitab, yaitu Nihâyah az-Zein fî Irsyâd al-Mubtadiîn (407 halaman), dan Qût alHabîb al-Gharîb Tausyîh 'alâ Fath al-Qarîb alMujîb (304 halaman). Enam dari delapan kitab karya Syekh Nawawi al-Bantani di atas dicetak dan diterbitkan dalam bentuk korasan, sedang dua kitab yang terakhir diterbitkan dalam bentuk mujallad. Alasan kenapa dua kitab terakhir diterbitkan dalam bentuk buku/dijilid atas dasar pertimbangan teknis. Karena jumlah halamannya cukup banyak, maka akan sangat menyulitkan pembaca jika diterbitkan dalam bentuk korasan.

Seluruh karya Syekh Nawawi al-Bantani dalam bidang ini berbentuk syarah. ${ }^{45}$ Tidak ada satupun dari delapan kitab fikih tersebut yang berbentuk matan. Hal ini diketahui dari judul kitab yang tertulis pada sampul, maupun halaman judul kitab. Delapan kitab tersebut secara tegas menyebutkan kata syarah (penjelasan) pada sampul dan halaman judul. Kata syarah ada yang ditempatkan di awal nama kitab, seperti kitab Syarah Sullam al-Munâjât, Syarah ar-Riyâdh al-Badî'ah dan Syarah 'Uqûd al-Lujain fî Bayân Huqûq az-Zaujain. Tetapi,

${ }^{44}$ Tiga dari delapan kitab tersebut diterbitkan dalam alMaktabah al-Syamilah edisi 53 GB versi 3.44, yaitu kitab Nihâyah al-Zein fî Irsyâd al-Mubtadiin, Kâsyifah al-SajâSyarah Safinah al-Najâ dan Syarah 'Uqûd al-Lujain fì Bayân Huqûq al-Zaujain. Ini menunjukkan popularitas Syekh Nawawi alBantani dan karya-karyanya di dunia Islam. Karya lain yang juga dimuat dalam al-Maktabah al-Syamilah adalah kitab tafsir al-Munir yang terkenal dengan sebutan Marâh Labîd li Kasyf Mảnâ al-Qur'ân al-Majî̀.

${ }^{45}$ Dalam halaman sampul dan halaman muka kitab biasanya dituliskan kata yang menunjukkan bahwa kitab tersebut berbentuk syarah. ada juga yang diletakkan di tengah-tengah, seperti kitab Nihâyah al-Zein fî Irsyâd alMubtadiîn Syarah Qurrah al-'Ain bi Mubimmât ad-Dîn, Mirqât Shu'ûd al-Tashdîq Syarah Sullam at-Taufiq, Kâsyifah as-Sajâ Syarah Safinah anNajâ, Bahjah al-Wasầil bi Syarah al-Masẩil dan satu lagi Qût al-Habîb al-Gharîb Tausyîh 'alâ Fath al-Qaîb al-Mujîb.

Tradisi penulisan kitab syarah ini sangat erat kaitannya dengan kebutuhan sumber belajar di kalangan santri Indonesia. Para ulama Indonesia, umumnya menyusun kitab syarah atas permintaan para kiai atau murid di Indonesia. Setelah menamatkan kitab matan atau kitab-kitab yang berskala kecil, mereka membutuhkan kitab yang lebih besar dengan penjelasan lebih luas. Dari sini para kiai/murid meminta ulama menyusun syarah dari kitab matan yang telah dikhatamkan atau syarah dari kitab matan yang lain. Hal ini diketahui dari pernyataan para ulama di dalam mukaddimah kitab syarahnya. Syekh Nawawi al-bantani, misalnya, dalam syarah Sullam at-Taufíq menulis bahwa penyusunan kitab syarah tersebut atas permintaan teman (murid)nya, ${ }^{46}$ terutama di Indonesia. Kitab Sullam at-Taufíq adalah kitab yang sangat popular dan paling banyak diajarkan di Indonesia. Ketika para santri telah mengkhatamkan kitab tersebut, mereka meminta kepada sang guru untuk melanjutkan pelajarannya ke jenjang yang lebih tinggi. Dan karena permintaan ini tidak dapat dipenuhi oleh sang kiai, maka ia meminta agar sang syekh menyusun syarah dari kitab yang telah dikhatamkan tersebut.

Sepanjang sejarah pesantren di Indonesia, kitab syarah memiliki kontribusi paling besar. Ia mendominasi kitab-kitab yang diajarkan di pesantren selama berabad-abad. Pengajaran kitab syarah juga mempengaruhi tradisi penulisan kitab syarah pada ulama Indonesia. Sebagian besar kitab fikih yang ditulis oleh ulama Indonesia merupakan komentar (syarah)

46 Syekh Nawawi al-Bantani, Syarah Sullam al-Taufiq, (Semarang: Toha Putra, t.th.), h. 2. 
dari kitab yang ditulis oleh ulama Timur Tengah atau India. Karya Abdus Shamad al-Falimbani, Yusuf Maqassari dan Syekh Nawawi al-Bantani misalnya, adalah komentar dari kitab-kitab karya ulama asing tersebut. Demikian juga kitabkitab yang dirujuk dalam penetapan hukum, sebagian besar merupakan kitab-kitab syarah. Dengan demikian dapat dikatakan bahwa syarah memiliki kontribusi yang amat besar terhadap tradisi akademik pesantren.

\section{Penutup}

Indonesia sebagai negara dengan jumlah penduduk terbesar di dunia telah mencetak sejumlah ulama besar sepanjang masa. Melalui sistem pengajaran di pesantren, tradisi pengkajian kitab kuning tetap dirawat sampai hari ini. Keberadaan kitab kuning tidak dapat dipandang sebelah mata dalam sistem pembelajaran di pesantren. Ia menjadi kurikulum utama di lembaga pendidikan milik kalangan tradisionalis Islam yang merupakan bagian terbesar dari umat Islam Indonesia. Para ulama Indonesia, mengambil peran penting dalam pelestarian tradisi ini, baik dalam bentuk penulisan kitab kuning (syarah dan matan), maupun dalam bentuk transmisi dan konservasi kitab-kitab karya ulama Timur Tengah atau lainnya. Melalui usaha-usaha merekalah, eksistensi kitab kuning yang didominasi kitab syarah dapat dipertahankan hingga hari ini.

\section{Pustaka Acuan}

Azra, Azyumardi, Jaringan Global dan Lokal Islam Nusantara, Bandung: Mizan, t.th..

Azra, Azyumardi, Pesantren: Kontinuitas dan Perubahan, dalam Nurcholish Madjid, BilikBilik Pesantren Sebuah Potret Perjalanan, (Jakarta: Dian Rakyat, t.th.

al-Bantani, Syekh Nawawi, Kâsyifah al-Sajâ Syarah Safinah al-Najâ, Surabaya: Maktabah Syekh Muhammad bin Ahmad Nabhan wa Auladih, t.th.

al-Bantani, Syekh Nawawi, Qût al-Habîb alGharîb Taushîh 'alâ Fath al-Qarîb, (Indonesia: Al-Haramain, 2005.
al-Bantani, Syekh Nawawi, Salâlim al-Fudhalâ, Pilang Wetan: Pesantren Hidayatul Mubtadi' in, t. th.

al-Bantani, Syekh Nawawi, Syarah Sullam alTaufiq, Semarang: Toha Putra, t.th.

al-Bajuri, Syekh Ibrahim, Hâsyiyah al-Bâjûrî̀ 'alâ Ibn Qâsim al-Ghuzzî̀, Semarang: Toha Putra, t.th. juz 1.

Bruinessen, Martin van, Kitab Kuning, Pesantren dan Tarekat, Yogyakarta: Gading Publishing, 2012.

Dasuqy, Muhammad, Muqaddimah fî Dirâsah alFiqh al-Islâmy, Qatar: Dar al-Tsaqafah, 2004.

Hidayat, Qomaruddin, Memahami bahasa Agama sebuah Kajian Hermeneutika, Bandung: Mizan, 2011.

Huda, Nor, Islam Nusantara Sejarah Sosial Intelektual Islam di Indonesia, Yogyakarta: ArRuzz Media, 2007

al-Hadhrami, Salim bin Samir, Matn Safinah al-Najâ, al-Maktabah al-Syâmilah edisi 53 $\mathrm{GB}$, versi 3.44.

Mochtar, Affandi, Kitab Kuning dan Tradisi Akademik Pesantren, Bekasi: Pustaka Isfahan, 2009.

Mochtar, Affandi, Kitab Kuning sebuah Observasi Umum, dalam Marzuki Wahid, dkk., Pesantren Masa Depan Wacana Pemberdayaan dan Transformasi Pesantren, Bandung: Pustaka Hidayah, 1993.

Maragustam, Pemikiran Pendidikan Syekh Nawawi al-Bantani, Yogyakarta: Datamedia, 2007.

Madjid, Nuholish, Bilik-Bilik Pesantren Sebuah Potret Perjalanan, Jakarta: Dian Rakyat, t.th.

al-Malibari, Zain al-Din bin Abd al-Aziz, Fath alMuî̀n li Syarah Qurrah al-Ain bi Muhimmât al-Dîn, Beirut: Dar al-Fikr, t.th.

Muhammad Syatha al-Dimyathi, Al-Sayyid Bakri ibn al-'Arif bi Allah al-Sayyid, I'ânah alThâlibîn, Semarang: Toha Putra, t.th., juz 1.

Mas'ud, Abdurrahman, Dari Haramain ke Nusantara Jejak Intelektual Arsitek Pesantren, Jakarta: Kencana Prenada Media Group, 2006. 
Nasuha, Chozin, Epistemologi Kitab Kuning, dalam Marzuki Wahid, dkk., Pesantren Masa Depan Wacana Pemberdayaan dan Transformasi Pesantren, Bandung: Pustaka Hidayah, 1999.
Wahid, Abdurrahman, Islam Kosmopolitan NilaiNilai Indonesia dan Transformasi Kebudayaan, Jakarta: The Wahid Institute, 2007.

Ziemek, Manfred, Pesantren dalam Perubahan Sosial, terj. Butche B. Soendjojo, Jakarta: P3M, 1986. 